\title{
Likelihood of Stachybotyrs atra sensitization in Canadian populations
}

\author{
DA Fischer ${ }^{*}$, Kim HL Barrie, ON Kitchener \\ From Canadian Society of Allergy and Clinical Immunology Annual Scientific Meeting 2009 \\ Halifax, Canada. 22-25 October 2009
}

\section{Purpose}

Stachybotrys atra has achieved great notoriety recently as a mould capable of producing mycotoxin, a potentially quite harmful substance. Because of news reports, patients have become quite concerned about "mould allergy" as the cause of an increasing number of symptoms. We set out to discover what percentage of patients referred to regional Allergy clinics have become sensitized to moulds, but especially Stachybotrys atra.

\section{Method}

Consecutive patients 12 years of age or older in 2007 were assessed in two separate clinics and prick tested to Stachybotrys atra (provided by Allergy Canada) in addition to the usual screen of allergens. Also noted were sensitization to mould spores in general and atopic status. Any positive skin test to any allergen would indicate atopy and any mould spore test that was positive would indicate mould sensitizatrion.

\section{Results}

2855 patients were enrolled, 1231 in Kitchener and 1624 in Barrie. The likelihood of atopy was 50\% in Kitchener and $62 \%$ in Barrie. The likelihood of mould sensitization in the atopic population was $18 \%$ in Kitchener and $21 \%$ in Barrie. The number of positive tests to Stachybotrys was 10 ( 2 true positives and 8 boarderline) in Kitchener and 11 ( 2 true positives and 9 borderline positives) in Barrie. This represents $0.6 \%$ of the total population tested and $1 \%$ of the atopic population.

\section{Conclusions}

Stachybotrys atra has been suggested to be a major cause of mould allergy recently in North America. Sensitization does not indicate true mold allergy but is a

University of Western Ontario, Canada marker for exposure in an atopic population. The extremely low level of sensitization suggests that Stachybotrys atra is not a significant cause of mould allergy in Ontario and is not required in an allergy screen.

Published: 12 May 2010

doi:10.1186/1710-1492-6-S1-P1

Cite this article as: Fischer et al.: Likelihood of Stachybotyrs atra sensitization in Canadian populations. Allergy, Asthma \& Clinical Immunology 2010 6(Suppl 1):P1.
Submit your next manuscript to BioMed Central and take full advantage of:

- Convenient online submission

- Thorough peer review

- No space constraints or color figure charges

- Immediate publication on acceptance

- Inclusion in PubMed, CAS, Scopus and Google Scholar

- Research which is freely available for redistribution

Submit your manuscript at www.biomedcentral.com/submit
C Biomed Central 